\title{
Hepatocyte metaplasia in experimental chagasic pancreatitis: preliminary report
}

\author{
Metaplasia hepatocítica em pancreatite chagásica experimental: nota prévia \\ Vitorino Modesto dos Santos', 3, Marcus Aurelho de Lima1, Marlene Cabrine-Santos², \\ Daniela de Stefani Marquez $z^{3}$, Eliane Lages-Silva ${ }^{2,3}$, Jaqueline Maria Matheus, \\ José Vitor de Oliveira Junior and Luis Eduardo Ramírez ${ }^{2,3}$
}

\begin{abstract}
Beginning the study of chronic pathologic changes in pancreas of hamsters experimentally infected with Trypanosoma cruzi Vic strain, hepatocyte metaplasia was observed in one animal from infected group. This is the first report of oncocytes in Chagas' disease, which could be due to aberrant regenerative response to pancreas inflammatory process.
\end{abstract}

Key-words: Hamster. Experimental Chagas' disease. Chronic pancreatitis. Oncocyte. Hepatocyte metaplasia.

Resumo Iniciando estudo de alterações patológicas crônicas no pâncreas de hamsters experimentalmente infectados com a cepa Vic de Trypanosoma cruzi, metaplasia oncocítica foi observada em um dos animais infectados. Este é o primeiro relato de oncocitos na doença de Chagas, que poderiam decorrer de resposta regenerativa aberrante ao processo inflamatório pancreático.

Palavras-chaves: Hamster. Doença de Chagas experimental. Pancreatite crônica. Oncocito. Metaplasia hepatocítica.

Hamsters infected with Trypanosoma cruzi may exhibit histopathological changes similar to human Chagas' disease $^{9}$, including pancreatitis ${ }^{6} 7$. Following injury and regeneration, pancreas ductular cells may give rise to metaplastic hepatocyte-like cells ${ }^{2510}$. Oxyphilic, oncocytic, ductular, hepatocytic or hepatocyte-like metaplasia has been described in older people ${ }^{11}$, in human chronic pancreatitis and diabetes mellitus ${ }^{11}$, and in spontaneous or experimentally induced tumors ${ }^{134812}$.

The complete study was planned in order to include the acute (first 60 days after the initial infection) and the chronic phase of experimental Chagas' disease up to 375 days. Just at the beginning of chronic pathologic and immunohistochemical evaluation in pancreas of hamsters experimentally infected with $T$. cruzi, oxyphilic metaplasia ${ }^{812}$ was observed in one of the infected animals. This is the first report of pancreas hepatocyte metaplasia in Chagas' disease.

Experimental procedures were in accordance with the Principles of Laboratory Animal Care from the National Society of Medical Search, and the Guide for the Care and use of Laboratory Animals from the National Institute of Health. The animals were housed ten per rigid plastic cage, with hardwood chip bedding and a 12-hr light/ dark cycle ${ }^{1}$. A standard industrial pelleted diet (54\% carbohydrate, $23 \%$ protein and $4 \%$ fat) supplemented with minerals, vitamins and amino acids, and tap water given ad libitum. Ten young male non-isogenic Syrian golden hamsters, which had been infected, and reinfected 75 days after, by intraperitoneal route, with 2,000 trypomastigote forms of the T. cruzi Vic strain were sacrificed on the $105^{\text {th }}$ day after initial infection. Ten weight and age-matched noninfected male hamsters constituted the normal control group studied.

The sacrifice and careful necropsy schedule included the $15^{\text {th }}, 30^{\text {th }}, 45^{\text {th }}, 60^{\text {th }}, 105^{\text {th }}, 180^{\text {th }}, 255^{\text {th }}, 330^{\text {th }}$ and $375^{\text {th }}$ day, and the reinfections were scheduled for the $75^{\text {th }}, 150^{\text {th }}$, $225^{\text {th }}$, and $300^{\text {th }}$ days of experiment. Fragments of pancreas were collected, and buffered formalin-fixed, paraffinembedded, $5 \mathrm{~m}$ sections were stained with hematoxylineosin and also submitted to immunohistochemical procedures. For immunohistochemical studies, the avidin-

\footnotetext{
1. Department of Internal Medicine, 2. Department of Biological Sciences and 3. Pathology Post-graduation Course of Triângulo Mineiro Medical School. Financial support: FUNEPU and CAPES/ICCTI.

Address to: Prof. Vitorino Modesto dos Santos. Depto de Medicina Interna/HE/FMTM. Praça Thomaz Ulhoa 706, 38025-050 Uberaba-MG, Brazil. Tel: 5534 3318-5258. Fax: 5534 3312-6640.

e-mail: parasito_fmtm@mednet.com.br

Recebido para publicação em 30/1/2001
} 
biotin-peroxidase method, antibodies anti-T. cruzi $(1: 3,000)$ and the islet cell specific antibodies: insulin $(1: 500)$, anti-glucagon $(1: 600)$, anti-somatostatin $(1: 3,500)$, and anti-pancreatic polypeptide $(1: 15,000)$ were employed. Statistical analysis was planned to include parametric and nonparametric methods.

At the $105^{\text {th }}$ day of experiment, major evidence of parenchyma hypotrophy, fibrosis and inflammatory infiltrate, characterizing pancreatitis, were invariably found in the infected group, while only minor changes were observed among the animals from control group.
Hepatocyte metaplasia was seen in a peri-insular zone of an infected animal (Figure 1), while the phenomenon was not observed in normal control hamsters. In both groups, normal islet-cells were positive to insulin, glucagon, somatostatin and pancreatic polypeptide antibodies, while oncocytes were all negative (Figure 2). The PAP-anti-Trypanosoma cruzi test was also positive in the pancreas sample where oncocytes were observed (Figure 3).

Hamster chronic pancreatitis, due to chagasic infection, was characterized by reduction in number and

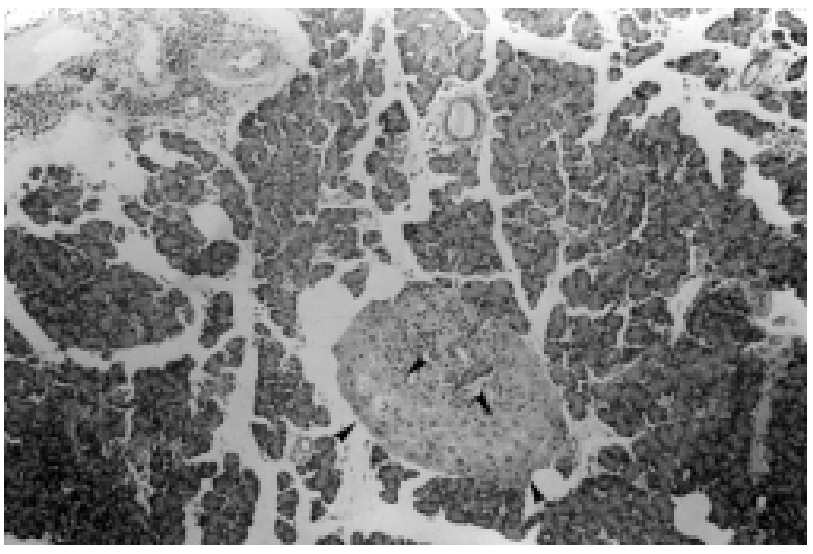

Figure 1 - Parenchyma hypotrophy and lymphocytic infiltrate diffusely distributed, including the islet. Peri-insular changes characterizing hepatocyte metaplasia (arrows) are observed (HE, X100).
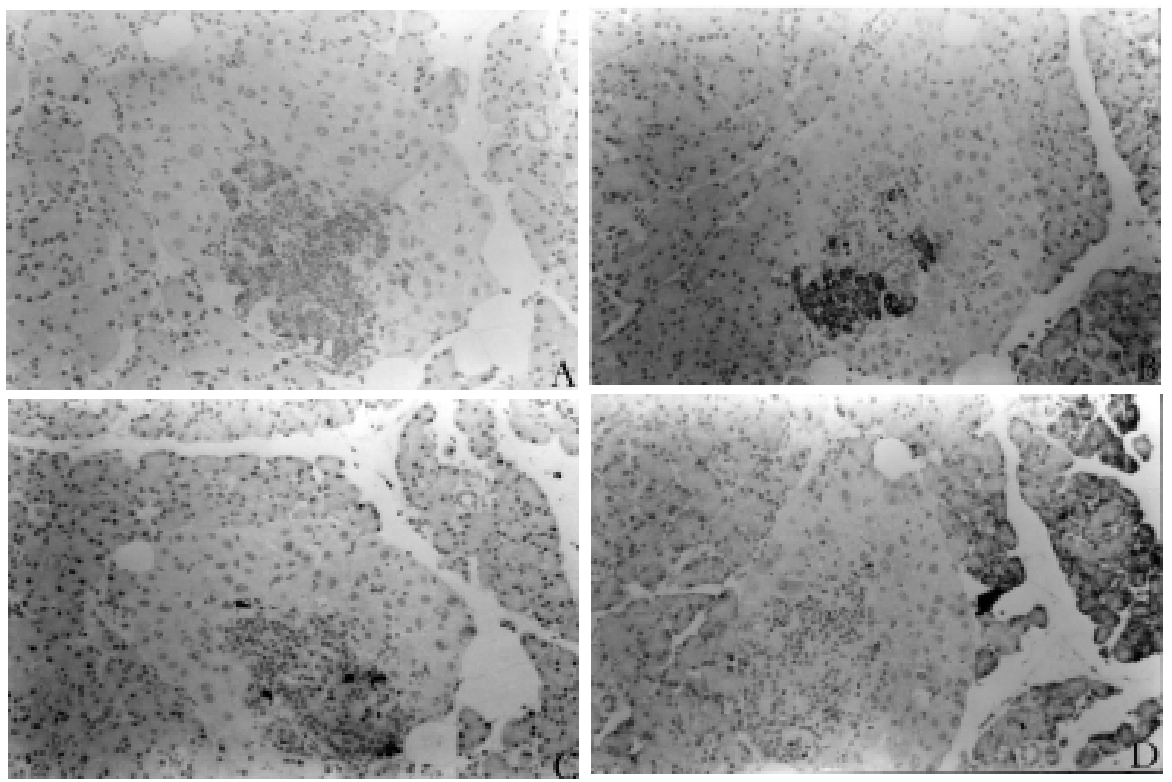

Figure 2 - On immunohistochemistry, normal islet-cells are positive to insulin (A), glucagon (B), somatostatin (C) and pancreatic polipeptide (D) antibodies, while oncocytes are negative (X400). 


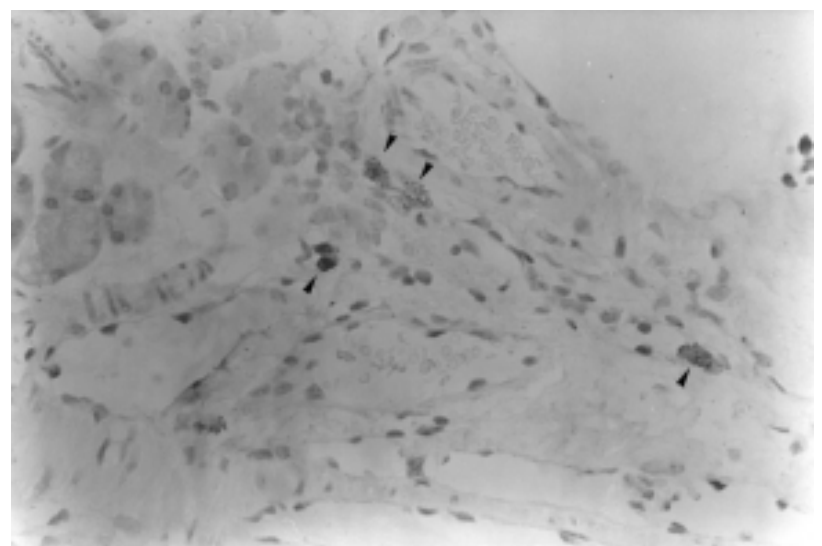

Figure 3 - PAP anti-T. cruzi test positive (arrows) in the pancreas sample where oncocytes were observed (x400).

size of acini and chronic inflammatory infiltrate around pancreas lobules and ducts, in addition to PAP anti- $T$. cruzi positive test in the same pancreas section.

The absence of oncocytes in animals of the noninfected group could suggest that the pancreas hepatocyte metaplasia is related with an aberrant response to the inflammatory process in Chagas' disease. Nevertheless, at the $105^{\text {th }}$ day of experiment, the number of animals already studied $(n=60)$ was not large enough to enable such a conclusion. Moreover, since oncocytic proliferation may become a more common event in association with animal aging ${ }^{11}$ and/ or with chagasic reinfection, the remainder $(n=155)$ normal control as well as infected hamsters will be appropriately evaluated after a longer period - up to $375^{\text {th }}$ day post-inoculation - as previously scheduled.
Only for the purpose of this preliminary report, the oncocytic nature of pancreas changes was based on the presence of large mitochondria, in addition to abundant, almost homogeneous, and finely granular eosinophilic cytoplasm observed under light microscopy ${ }^{812}$. However, for more convincing evidence of the phenomenon, further evaluation of the oncocytes will include liver-specific markers and ultrastructural details.

The occurrence of pancreas hepatocyte metaplasia in Chagas' disease was not previously described. Although the authors consider it inadequate to extrapolate this very preliminary finding to human cases, the concern is an eventual relationship between Chagas' disease and pancreas oncocytes.

\section{REFERENCES}

1. Konishi N, Ward JM, Waalkes MP. Pancreatic hepatocytes in Fischer and Wistar rats induced by repeated injections of cadmium chloride. Toxicology Applied Pharmacology 104:149156, 1990.

2. Makino T, Usuda N, Rao S, Reddy JK, Scarpelli DG. Transdifferentiation of ductular cells into hepatocytes in regenerating hamster pancreas. Laboratory Investigation 62:552-561, 1990.

3. Monis B, Valentich MA, Urrutia R, Rivolta M. Multicentric focal acinar cell hyperplasia and hepatocyte-like cell metaplasia are induced by nitrosomethylurea in rat pancreas. International Journal of Pancreatology 8:119-131, 1991.

4. Pacchioni D, Papotti M, Macri L, Forte G, Bussolati G. Pancreatic oncocytic endocrine tumors. Cytologic features of two cases. Acta Cytologica 40:742-746, 1996

5. Rao MS, Reddy JK. Hepatic transdifferentiation in the pancreas. Seminars in Cell Biology 6:151-156, 1995.

6. Ramirez LE, Lages-Silva E, Chapadeiro E. Hamster. In: Jorge TCA, Castro SL (eds) Chagas' disease. Manual for animal experiment. FIOCRUZ, Rio de Janeiro RJ, p.145-148, 2000.
7. Ramirez LE, Lages-Silva E, Soares-Junior JM, Chapadeiro E. The hamster (Mesocricetus auratus) as experimental model in Chagas' disease: parasitological and histopathological studies in acute and chronic phases of Trypanosoma cruzi infection. Revista da Sociedade Brasileira de Medicina Tropical 27:163-169, 1994.

8. Sadoul JL, Saint-Paul MC, Hoffman P, Plazza M, Birtwisle Y, Freychet P, Loubiere R. Malignant pancreatic oncocytoma. An unusual cause of organic hypoglycemia. Journal of Endocrinological Investigation 15:211-217, 1992.

9. Santos VM, Teixeira VPA, Cunha DF, Cunha SFC, Monteiro JP, Santos JAM, Santos TAM, Santos LAM. Pancreatic anatomopathology changes in chronic chagasic women. Preliminary data. Arquivos de Gastroenterologia 36:127-132, 1999.

10. Sirica AE. Ductular hepatocytes. Histology and Histopathology 10:433-456, 1995

11. Tasso F, Sarles H. Cellules canalaires et oncocytes dans le pancreas humain. Étude comparée à l'état normal et dans les pancréatites chroniques. Annales D'Anatomie Pathologique 18:277-300, 1973

12. Wenig BM, Heffess CS, Adair CF. Atlas of Endocrine Pathology. WB Saunders, Philadelphia, 1997. 